MUSEUMS

\section{Mammals on Show}

THE new Pleistocene mammal gallery at the British Museum (Natural History) was opened to the public for the first time last Tuesday. It contains eighteen impressive displays of Pleistocene mammals prepared for the museum by Previews, with the help of the museum's modellers, and it is the first step in the reconstruction of the entire fossil mammal gallery. One of the most striking exhibits is the giant Irish deer shown in the figure, with a lifelike scale reconstruction in the foreground, and set against an almost surrealist background representing the Dublin district as it might have looked 11,000 to 12,000 years ago.

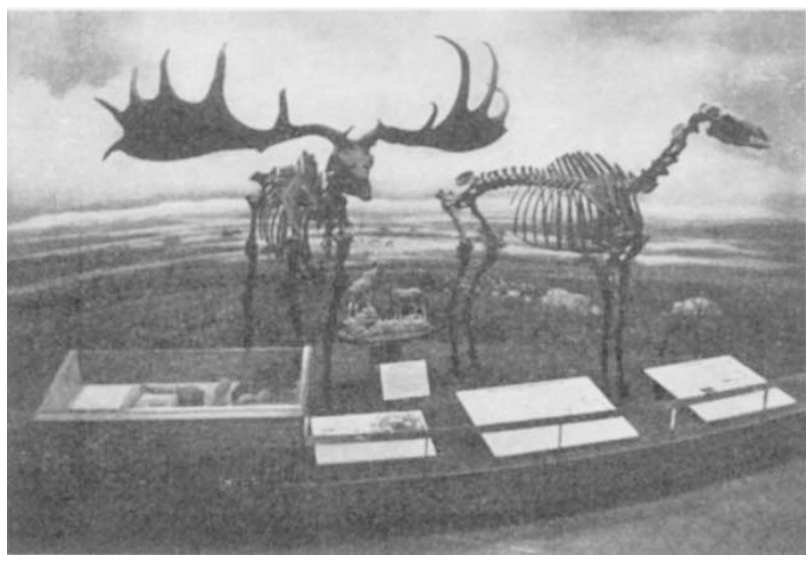

Male and female giant Irish deer against a background depicting a landscape near Dublin about 12,000 years ago. The remains of these animals are still found in peat bogs in many parts of Ireland.

There are also exhibits of the famous London elephants found at Aveley in Essex in 1964 and cases depicting the origin, evolution and faunas of the Thames terraces, and several other cases illustrate the Pleistocene deposits and faunas from other parts of Britain. Apart from the giant deer and the elephants, the most eye-catching display of mammals from farther afield is the huge centre piece of the exhibition which shows some of the mammals, such as the giant ground sloth and the giant armadillo, which reached extraordinary shapes or sizes in the Pleistocene of South America. East Africa is represented by an informative series of cases showing the geology and fauna of the Olduvai Gorge made famous by Dr L. S. B. Leakey and his colleagues.

If the prize for the most bizarre in the exhibition goes to the giant armadillo, then the prize for the most unusual must be awarded to the plaster cast of the woolly rhino found in 1929 -in a remarkable state of preservation through being pickled in salt and oil-in Pleistocene deposits in Staruna in the eastern Carpathians. The original specimen is in the Zoological Museum in Cracow and a cast has been specially presented to the Natural History Museum for its new gallery by the Polish Academy of Sciences.

A gallery such as this must cater for all levels of taste. Visitors intent on learning as well as looking should be prepared with a large notebook and with good eyesight; the stalwart will find plenty of interesting facts to note down.

\section{ROMANIA}

\section{After the Flood}

IN April and May this year, a rapid thaw combined with torrential rain caused all the rivers of Romania to burst their banks. At least 161 people died in the ensuing floods and some 268,000 were evacuated from their homes; livestock suffered badly and landslides over large areas added to the destruction of agricultural land and industrial plant. The Centre for Shortlived Phenomena at the Smithsonian Institution has now released reports from Bucharest which discuss the unusual coincidence of weather conditions that caused the flooding, and also show that the Romanians have been quickly repairing the damage.

Early in May, according to Marcian Bleahu, director of the Geological Institute in Bucharest, there was a heat wave which was broken up as a deep depression moved in over the Eastern Carpathians. The air of the depression was $10^{\circ}-15^{\circ} \mathrm{C}$ colder than that of the hot area, and this caused $100 \mathrm{l} . \mathrm{m}^{-2}$ of rain to fall during two days in regions where the usual maximum is something like $60-801 . \mathrm{m}^{-2}$ in a month. Spectacular flooding ensued-the Mures River, for example, ran at $20 \mathrm{~km} \mathrm{~h}^{-1}$ and in some places reached $6 \mathrm{~m}$ above the low water level. More rain later in the month added to the floods which spread over the country until the beginning of June and which moved on into Hungary. Nearly a million hectares of land were under water.

By the middle of June, however, nearly half of the 636 bridges that had been damaged or destroyed were rebuilt, and 113 of the 146 flooded industrial installations were back in operation, although more than 60,000 evacuees remained homeless. But the toughest job seems to be the repairing of railways and roads that were destroyed by landslides, as well as vineyards and orchards which were obliterated on a large scale. Electric power, at least, has now been restored almost everywhere.

\section{SOVIET UNION \\ farming in the Clouds}

\section{from our Soviet Correspondent}

Promising results have been announced by the Institute of Pedology of the Tadjik SSR from its expedition to survey the soil and water resources of the Pamir mountains. The goal of the survey is that "the Pamirs shall blossom".

The soil chemistry and botany of an area of more than 300,000 hectares in the Eastern Pamirs have been surveyed in detail. The area contains considerable massifs which are suitable for the cultivation of many crops, once the region is developed for agriculture. The many mountain rivers of the region will provide a convenient source for the irrigation of the valleys above the cloudline.

The plateau of the Eastern Pamirs, which is also above the cloudline, is recommended for pasturage. The 150,000 hectares of high slopes have a guaranteed water supply from local rivers, while the Rangul'skaya depression could be irrigated from the subterranean freshwater springs found in the area. It has been estimated that by irrigation and sowing with specially sclected grasses, the productivity of the local pastures could be increased at least ten-fold, and possibly as much as twenty-fold. 